\title{
Assessing competencies: the student portfolio in an optics course
}

\author{
Jesús Armengol, Fidel Vega
}

Jesús Armengol, Fidel Vega, "Assessing competencies: the student portfolio in an optics course," Proc. SPIE 9664, Ninth International Topical Meeting on Education and Training in Optics and Photonics, 96640F (24 October 2005); doi: $10.1117 / 12.2207709$

SPIE Event: Ninth International Topical Meeting on Education and Training in Optics and Photonics, 2005, Marseille, France 


\title{
Ref ETOP049
}

\section{Assessing competencies: the student portfolio in an optics course}

\author{
Jesús Armengol \& Fidel Vega
}

Optics and Optometry Department. ,Universitat Politècnica de Catalunya (UPC), C/ Violinista Vellsolà, 37.08222-Terrassa. SPAIN, (Jesus.Armengol@upc.edu),

\begin{abstract}
The student portfolio is an ideal tool to assess competencies. In a portfolio, students must be able to show their progress towards the acquisition of learning outcomes. Students must convince teachers of their learning.

The implementation in our case (first year wave optics course) consists in a collection of all the work done during the semester. It contains summaries of text books, resolved problems, laboratory reports, electronic materials from the web, sketches.... It also contains documents with the reflections on his own way of learning: how he studies, what are his weaknesses and strong points.
\end{abstract}

\section{Keywords}

Student portfolio, assessing competencies, active learning, innovation in education.

\section{Summary}

\section{Introduction}

"Students become far more sophisticated and educated when they can organize their work into a portfolio that represents the quality of their learning in a course or college year. (...)The resulting portfolio may feature the student's 'best work' or the 'process' the student is using to learn. "[i]

The student portfolio is an ideal tool for assessing competencies ${ }^{[i]}$. It is widely used in pedagogical studies ${ }^{[i i i]}$. In recent years, it has come to be used in education at all levels and in all areas ${ }^{\text {[iv] }}$. The main benefits of portfolios are that they enable instructors to assess how well students have learned; they give students an opportunity to demonstrate that they have thoroughly learnt a subject, and to think about their individual learning processes; they increase students' motivation to learn; they provide opportunities and data to assess their progress; and they make students responsible for the assessment process.

\section{Our experience}

Starting in 2002, we introduced student portfolios as a new element in the assessment process of our first-year course in wave optics for students studying optometry.

The main objective was to increase our students' autonomy in their individual learning processes. We wanted to encourage a learning process that would be characterised by reasoning and reflection rather than being strategic and mechanical. The portfolio was intended 
to be used by the students to reflect the manner in which they learnt, what material they had really learnt, and what they still needed to focus on and how to go about doing it.

Implementing portfolios in our study consisted in having students compile a collection of all the work they had done over the course of the semester. Every student would have his or her own portfolio, which would contain items such as summaries of textbooks, the problems they had solved, their laboratory reports, online resources they had located and sketches. It was also to contain documents in which they expressed their reflections on their individual learning processes: how they studied, and weaknesses they could improve and strong points they could reinforce.

The portfolio itself was required to contain the following elements:

- A brief curriculum vitae (one page at most), in which students introduced themselves and stated what had motivated them to study and what they hoped to achieve from the course.

- All the work carried out by the student during the course, dated and arranged in chronological order. The work undertaken in groups was also to be collected by each member.

- One document at the end of each module (for each of the five modules in the semester) summarising the student's reflections on the activities he or she had undertaken to study during that module. They also had to include a log of the time they had dedicated to their studies (both individually and in groups), a list of everything they had learnt in the module and anything they felt needed to be improved.

o Two documents, one at the middle and one at the end of the course, in which students were asked to reflect on their individual learning processes. They were also asked to characterise their groups and describe the personal contributions they made to them.

Even though the portfolio was given a clear structure, it need not be a form to be merely filled in. Improvisation must be made possible and creativity must be encouraged.

The assessment was carried out in three interviews over the course of the semester-a frequency that strikes a balance between a commitment to "continuous" assessment and a reasonable workload for the instructor. The quantity and quality of each student's work was assessed. Furthermore, generic skills, such as the ability to synthesise information, the capacity to communicate effectively and to structure information were also evaluated. 


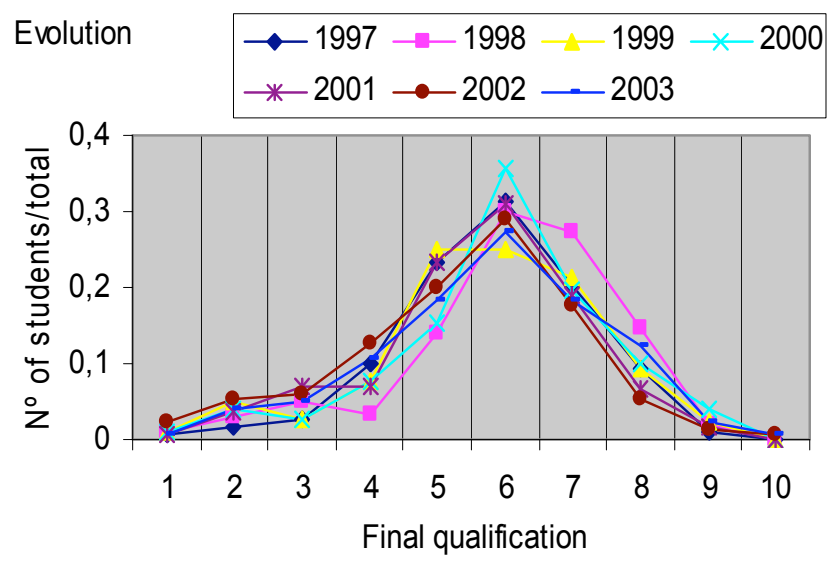

Figure1.- Evolution of final qualifications

\section{Results and conclusions}

The introduction of a portfolio in the assessment process of our course has proved to a very positive experience: students were motivated to work continuously and their individual learning processes have been enhanced, while instructors have come to know their students better and have shown a greater degree of confidence in the assessment process.

Proc. of SPIE Vol. $966496640 \mathrm{~F}-3$ 
The portfolio was introduced gradually. The weight it carried in the final mark was initially $20 \%$ and has since been increased to $30 \%$. A number of controls were established in the process, and as the evolution of the final marks over the last several years has not shown any critical variations (see fig. 1), we believe that at the very least the academic level of the course has been maintained. The correlation between the marks given to the portfolios and the final marks has proved to be quite good (see fig.2), and accordingly, the use of the student portfolio seems to be a useful tool for assessing students' knowledge.

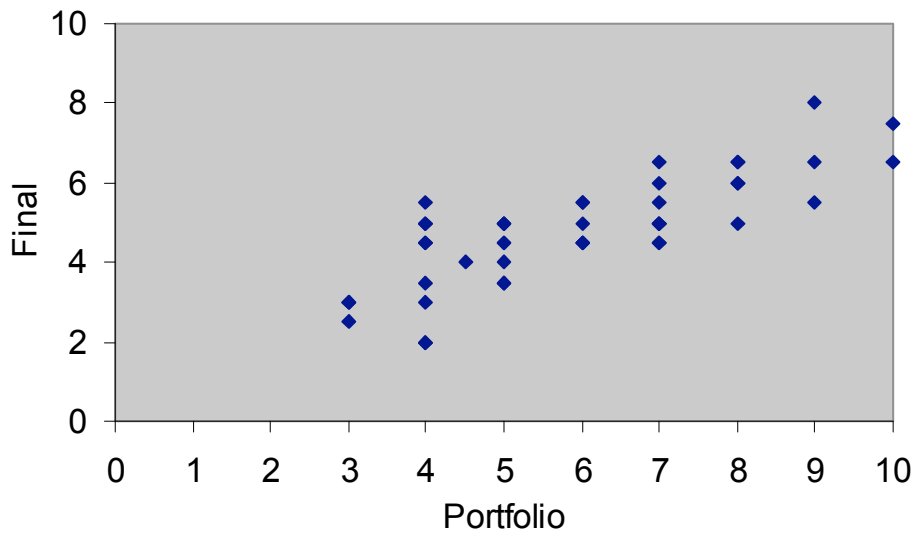

Figure 2.- Correlation between marks

\section{References}

${ }^{1}$ D. W. Johnson, R. T. Johnson, K. A. Smith, "Active Learning: Cooperation in the College Classroom," Interaction Book Company, Edina, MN, 1991

1 -C. Poyatos, C. Allan, "The use of learning portfolios to develop generic skills: An evaluative case study with on-line Industrial Relations students", ETL Conference, 2003, Queensland College of Art, Griffith University

-Classroom Assessment Portfolios. http://www. flaguide.org/cat/portfolios/portfolios1.php

${ }^{1}$-Electronic Portfolios in Teacher Education. Carla Hagen Piper. http://www.chapman.edu/soe/faculty/piper/EPWeb/toc.html

1 - Queensland University of Technology. http://www.studentportfolio.qut.edu.au/overview/

-The Kalamazoo College Portfolio.- http://www.kzoo.edu/pfolio/

-Dr. Helen Barrett, http://electronicportfolios.org 